\title{
SOME BRACHIOPOD GENERA OF THE SUBFAMILY STROPHOMENINAE FROM THE ORDOVICIAN OF ESTONIA
}

\author{
Arvo ROOMUSOKS
}

Tartu Olikooli Geoloogia Instituut (Institute of Geology, University of Tartu). Vanemuise 46, EE-2400 Tartu, Eesti (Estonia)

Received October 3, 1992; accepted March 23, 1993

\begin{abstract}
Emended diagnosis is proposed for the genus Actinomena (Öpik, 1930). Actinomena asmusi (Verneuil, 1845) is included to the genus Longvillia Bancroft, 1933. Two new genera are erected: Keilamena, type species Actinomena occidens Männil in Oraspõld (Ораспыльд, 1956), and Rugomena, type species Rugomena adilensis sp. n. For the genera Microtrypa Wilson, 1945, Trigrammaria Wilson, 1945, and Luhaia Rõõmusoks, 1956, new data of distribution are presented.
\end{abstract}

Key words: Strophomenida, Ordovician, Estonia.

In the Ordovician sequence of Estonia four genera of the subfamily Strophomeninae, Actinomena, Microtrypa, Trigrammaria, and Luhaia, have hitherto been recorded. The subgenus Strophomena (Actinomena) Öpik was raised to generic rank already by Sokolskaya (Сокольская, 1954). Besides the type species S.(A.) orta, Opik included in Strophomena (Actinomena) four subspecies from the Kukruse Stage, Orthis asmusi Verneuil from the Keila Stage, and some Upper Ordovician species (Öpik, 1930 , p. 166). According to Sokolskaya (Сокольская, 1954) O. asmusi was a Strophomena, whereas Oraspõld (Ораспыльд, 1956) regarded the species together with a new species occidens as representatives of Actinomena. Spjeldnaes (1957) was mistaken treating Actinomena as a synonym to Kjerulfina; he included also $A$. asmusi in this genus. In this paper $A$. asmusi and $A$. occidens are not considered as congeneric with $A$. orta. The former species is very similar to Strophomena grandis Sow, the type species of Longvillia Bancroft, 1933. The latter species, A. occidens Männil in Oraspõld (Ораспыльд, 1956), is here selected as the type species for the new genus Keilamena.

Spjeldnaes (1957) described three new species of Strophomena (S. norvegica, S. hirsuta, S. steinari) from the Upper Caradoc of Norway. He mentioned that Strophomena includes both species with a comparatively coarse undifferentiated sculpture, and those with fine, well differentiated sculpture. The latter species might perhaps be included in Longvillia (Spjeldnaes, 1957, p. 140). Subsequently Williams (1963, p. 452) redescribed and figured $S$. grandis, which distinctly differs from the other species of Strophomena in shape and sculpture. In spite of this Williams (1965) regarded Longvillia as a junior synonym of Strophomena. Cocks (1990) has now asked the International Commission on Zoological Nomenclature to designate the well-known species Leptaena planumbona Hall as the type species of Strophomena. Proceeding from 
this, all species of Baltoscandian Strophomena should probably be assigned to other genera. During a visit to Oslo in 1991 I examined the types of Holtedahl (1916) and Spjeldnaes (1957) in Paleontologisk Museum. As a result it could be asserted that a true Strophomena does not occur in the Viruan of Baltoscandia. Strophomena norvegica Spjeldnaes might be included in Longvillia, S. steinari Spjeldnaes, and perhaps S. hirsuta Spjeldnaes, in Keilamena gen. n.

The types of the species described by Öpik are housed in the Institute of Geology, Estonian Academy of Sciences, Tallinn. The types of the new species are housed in the Museum of Geology of Tartu University $(\mathrm{Br}$ marking the brachiopod types catalogue numbers).

\section{Genus Actinomena Öpik, 1930}

Type species (by original designation). Strophomena (Actinomena) orta Öpik, 1930, p. 166; pl. X, figs. 131, 132, 135 (see Pl. I, figs. 1-9 in the present paper) from the Kukruse Stage, Kiviõli Member of Viivikonna Formation (U. Llandeilo), North Estonia.

Diagnosis (emended): Medium-sized thin-shelled resupinate Strophomeninae with almost flat, semielliptical ventral disc, and long ventrally deflected trail. Geniculum rounded. Ornament strongly unequally parvicostellate with widely spaced accentuated costellae. Short weak oblique wrinkles along hinge line laterally at umbo. Ventral muscle field small, elongately subquadrate in outline and with short, low subparallel bounding ridges. Adductor scar broad, weakly raised. Cardinalia small. Two pairs of weakly developed transmuscle septa. Extra-muscular area densely and finely, irregularly pseudopunctate.

Discussion. Actinomena differs from Strophomena in having stronger resupination and a long trail (mostly broken off), weakly oblique wrinkles, strongly unequally parvicostellate ornament, and by the character of the ventral muscle field.

Distribution. The type species is known only from the Kukruse Stage. A still undescribed new species occurs in the underlying Uhaku Stage (L. Llandeilo). Another undescribed species of Actinomena occurs in Dalby Limestone (mostly equivalent of the Kukruse Stage) on Öland and in the Siljan district, Sweden (Jaanusson, 1960, 1963). Actinomena sp. from the Killey Bridge Formation (Middle Ashgill) of Ireland, described by Mitchell (1977), has flatly convex valve profiles, the shell is not resupinate, and the ventral interior is unknown. This species perhaps belongs to a new genus, related to Rugomena gen. n.

Thus Actinomena seems to be a genus endemic for Baltoscandia occurring in beds equivalent to the Pygodus anserinus Conodont Zone of Bergström (1971).

\section{Genus Microtrypa Wilson, 1945}

The first representative ascribed to Microtrypa from the Ordovician of Europe is $M$. cassata Williams from the Scottish Craighead Limestone (U. Caradoc) (Williams, 1962). Three other species of this genus were recently described from Baltoscandia by the author (Rõõmusoks, 1985). They are $M$. estonica from the Oandu and Rakvere stages, M.? minima from the Rakvere Stage (U. Caradoc till L. Ashgill), Estonia, and $M$. oelandica from the Gräsgård Siltstone boulders (topmost Caradoc), Oland, Sweden. 
Now the author has examined the types of Strophomena keilhaut Holtedahl (1916, p. 53; pl. VII, fig. 8) and Spjeldnaes (1957, p. 146) in Paleontologisk Museum, Oslo. These specimens, plus two interiors of the ventral valve on the reverse side of the sample collected from the top of Mjøsa Formation (roughly equivalent to the Rakvere Stage of Estonia; Spjeldnaes, 1982; Owen et al., 1990), seem to be related to M. estonica Rõõmusoks. The European forms probably represent invading elements of the fauna from North American Midcontinent, where this genus occurs in much older strata (Wilson, 1945; Cooper, 1956), equivalents to N. gracilis to D. multidens zones (Bergström, 1971).

\section{Genus Trigrammaria Wilson, 1945}

Occurrence of this originally North American Midcontinent stock (known mainly from the Ottawa Formation) in the Ordovician of Baltoscandia was first mentioned by Jaanusson (1982, p. 28, 33, 39), who referred to an undescribed Trigrammaria sp. n. A. from the Molda and Skålberg limestones (= equivalents of the Oandu Stage in Estonia) in the Siljan district, Sweden. This species was later described by the author as T. valdari (Rõõmusoks, 1985, p. 135). Another Upper Caradoc form is Trigrammaria sp. from the Gräsgård Limestone boulders on Öland, and from a probably contemporaneus limestone glacial boulder at Boltenhagen, North Germany (Rõomusoks, 1985, p. 136). It is interesting to note that from the latter boulder the author has identified some species which are characteristic of the upper part of the Keila Stage in Estonia together with Toxochasmops cf. extensus (Boeck). Thus, Trigrammaria sp. mentioned above may be the oldest representative of the genus in Baltoscandia. The youngest known species of the genus - T. virve - occurs in the Nabala Stage, Paekna Formation (L. Ashgill) in North Estonia (Rõomusoks, 1985, p. 134). Thus, in Baltoscandia the occurrence of both Trigrammaria and Microtrypa is within the Amorphognathus superbus Conodont Zone as defined by Bergström (1971).

\section{PLATE I}

Figs. 1-9. Actinomena orta (Öpik), all from Kukruse Stage, Viivikonna Formation. 1 - dorsal exterior 201 (133) $(\times 2)$. Kohtla. Figured by Öpik (1930, pl. X, fig. 133). $2-4$ - ventral, lateral, and posterior views $(\mathrm{Br} 1502)(\times 2)$. Kohtla, coll. A. Öpik. $5-6$ - dorsal interior $(\times 2$ and $\times 5)$. Kohtla. Figured by Öpik $(1930$, pl. X, fig. 135). 7 - ventral interior $(\times 2)(\mathrm{Br} 1504)$. Kohtla, coll. A. Opik. 8 - ventral interior (×4.4) (Br 1515). Küttejõu, coll. author, 1964. 9 - dorsal interior $(\times 3)(\mathrm{Br} 2401)$, Kohtla. Figured by Oraspõld (Ораспыльд, 1956, pl. III, fig. 6).

\section{PLATE II}

Figs. 1-5. Luhaia vardi Rõõmusoks, all from Pirgu Stage, Adila Formation. 1 - dorsal mould. Holotype $(\times 1)$ ( $\mathrm{Br}$ 4004). Hosholm, Vormsi Island, coll. V. Jaanusson, S. Kiin, and R. Männil in 1939. 2 - posterior view $(\times 2)$ ( $\mathrm{Br} 1611)$. Haapsalu, coll. V. Reimer. 3-4 - posterior and lateral views $(\times 2)(\mathrm{Br} 4003)$. Uuemõisa, coll. B. Stein. 5 ventral view $(\times 2)(\mathrm{Br}$ 1607). Hosholm, Vormsi Island, coll. V. Jaanusson, S. Kiin, and R. Männil in 1939. Figs. 6-7. Luhaia sp. n., ventral and dorsal interior ( $\times 3$ ) (G 1010, Paleontologiska Museet, Uppsala). Ojle Myr Limestone (block 17), Gotland, coll. O. W. Wennersten in 1897; photo L. Ramsköld. 

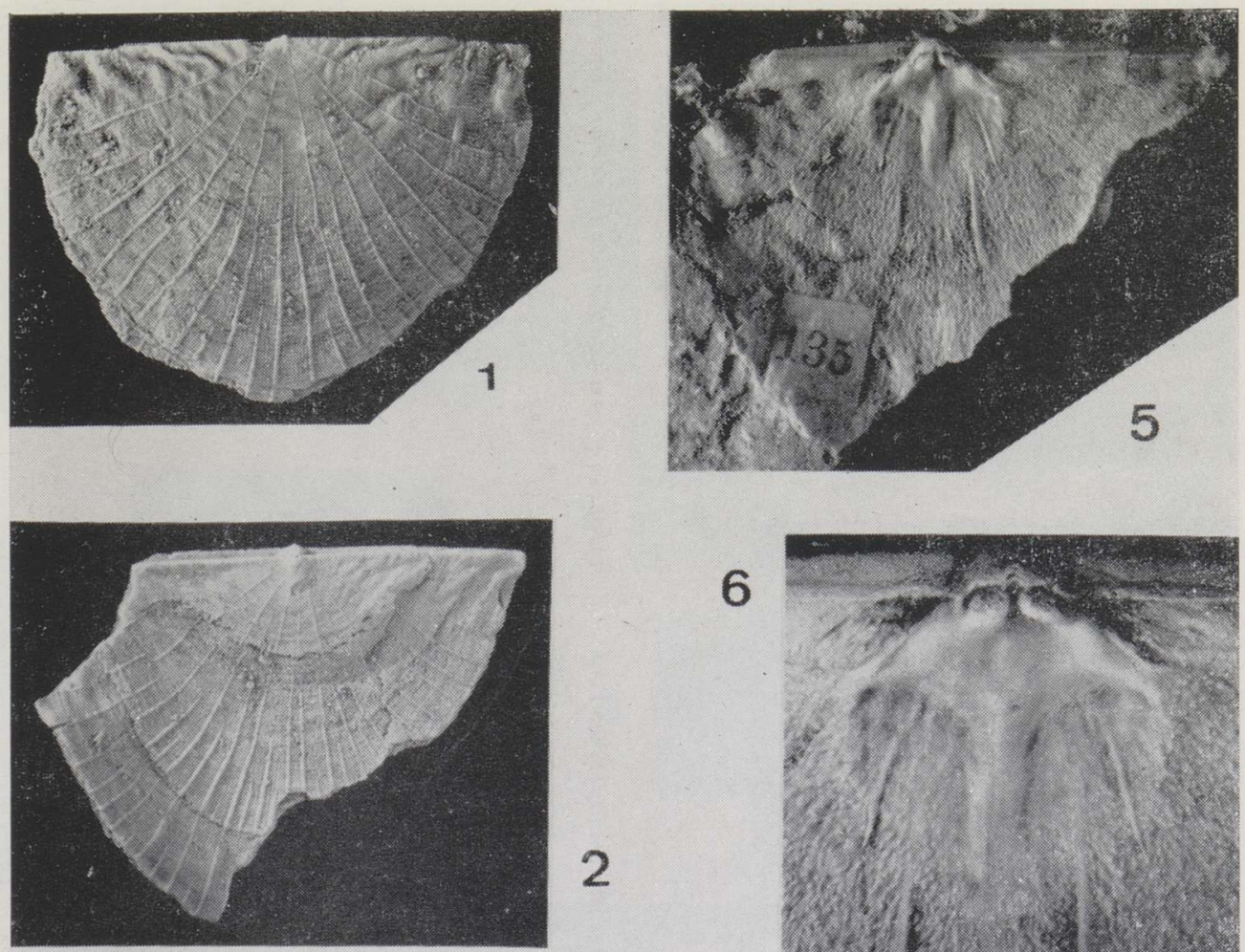

2
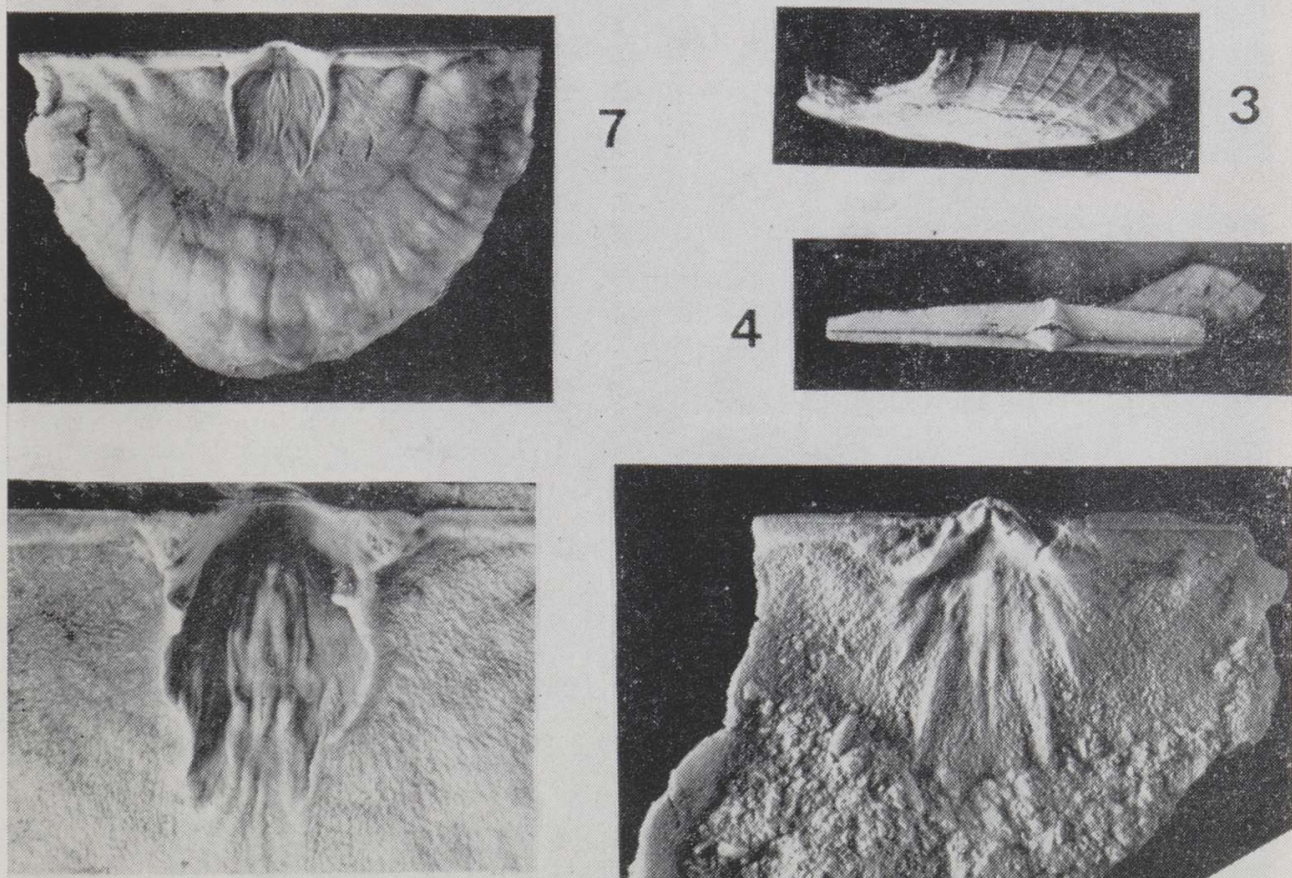

8

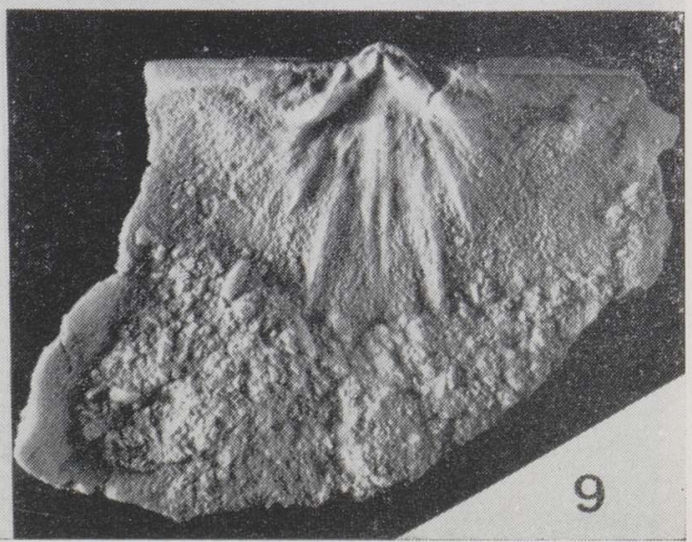


PLATE II
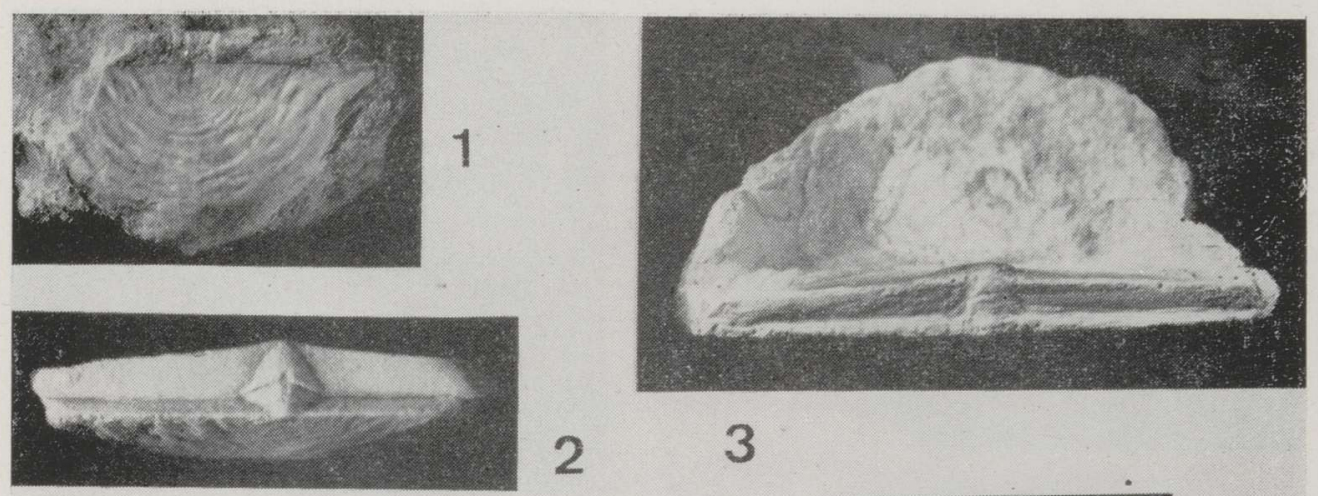

2
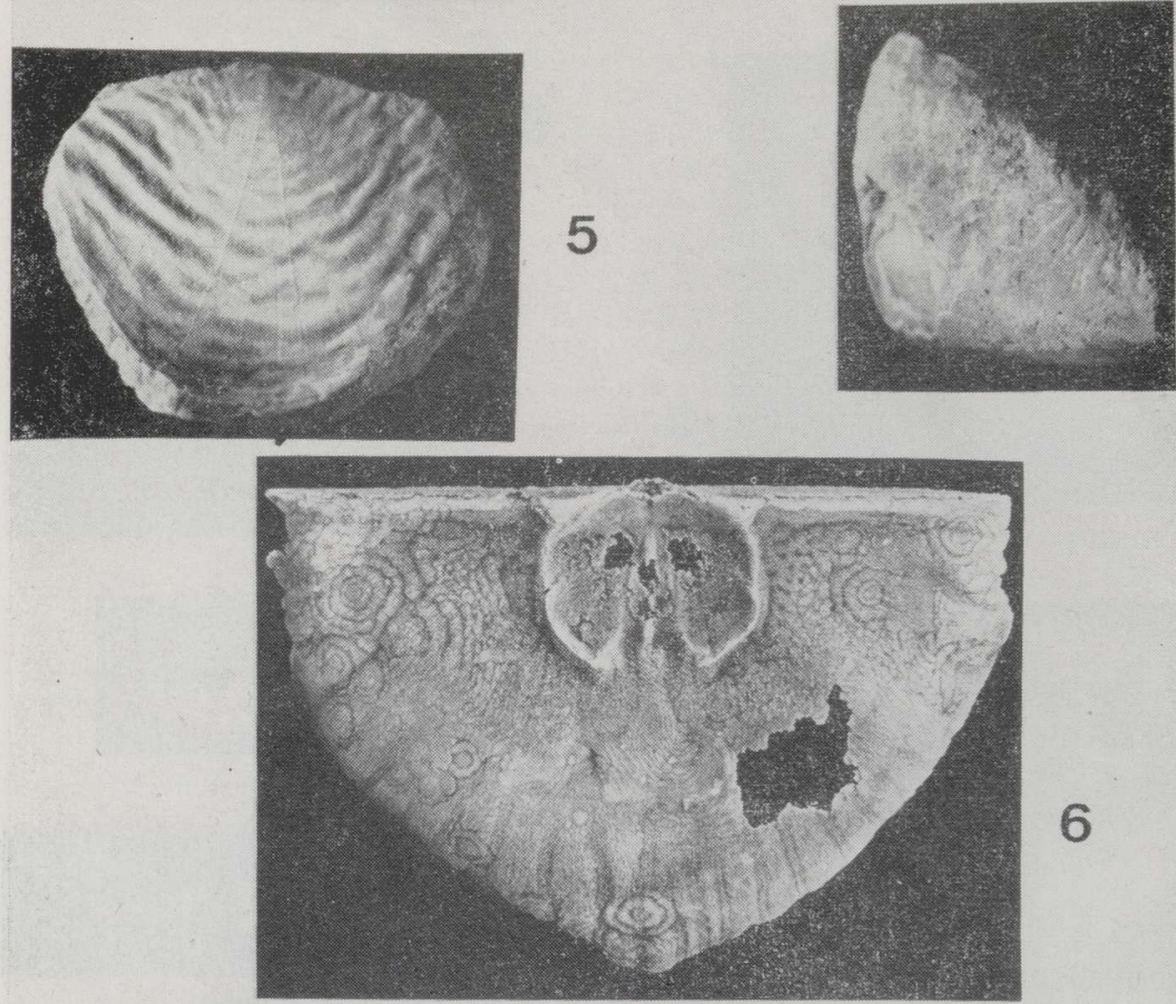

6

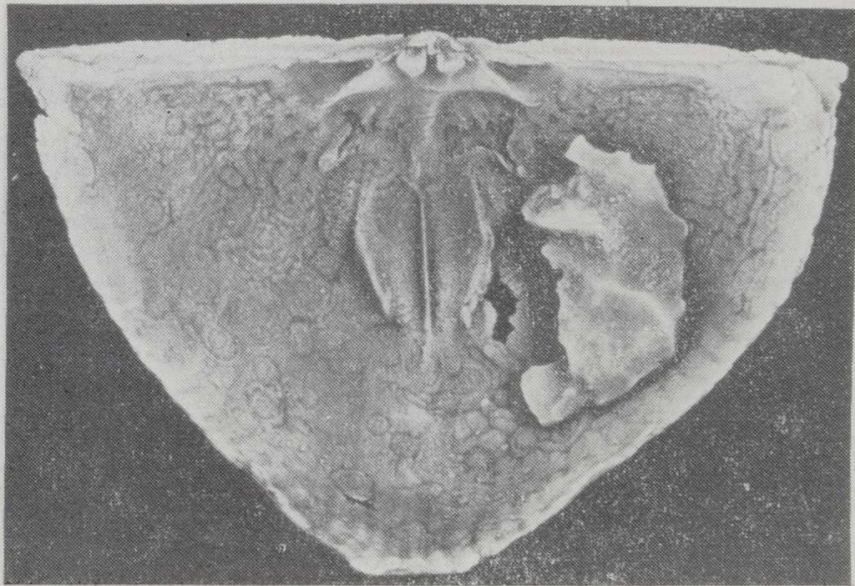



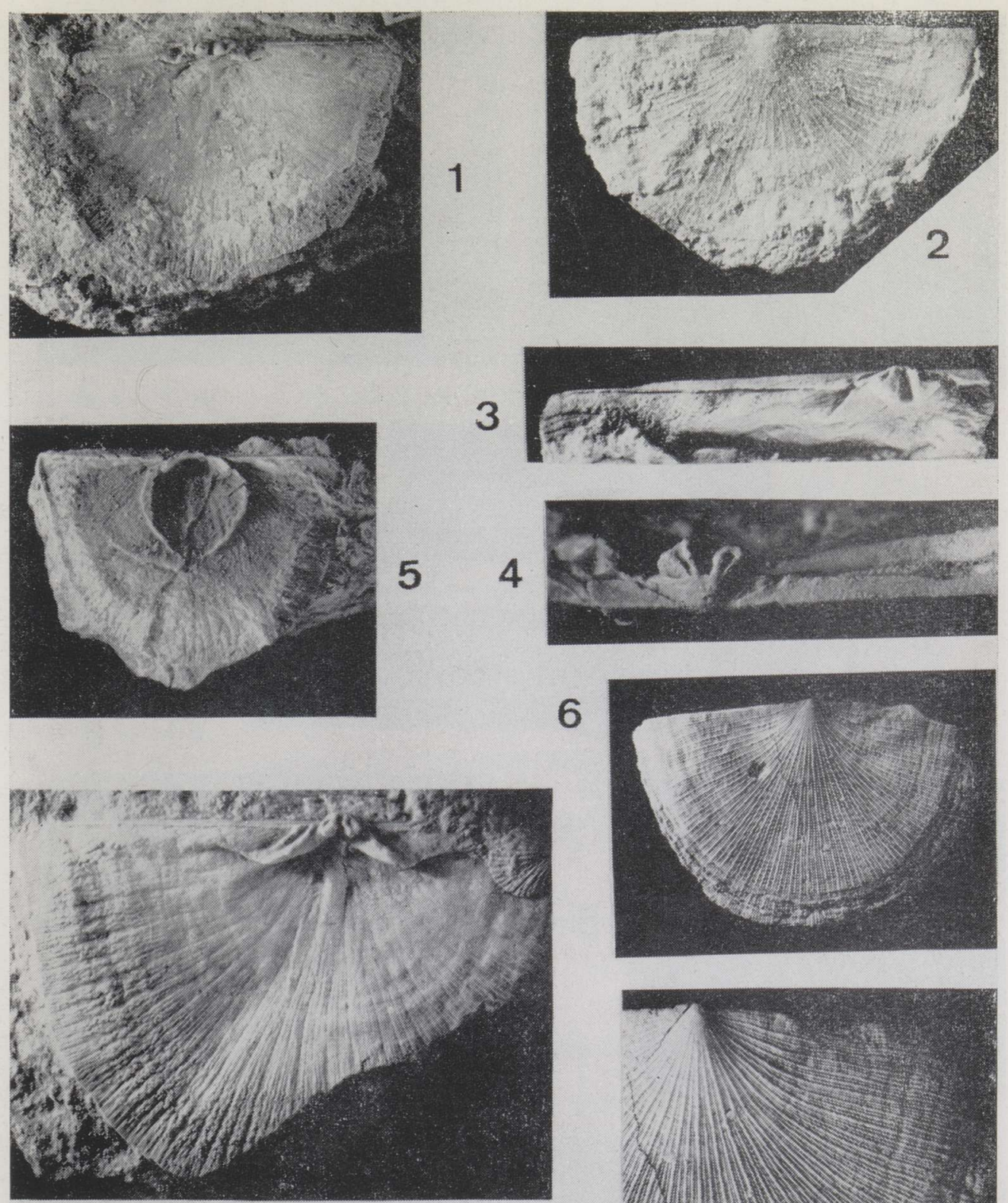

8

\section{9}

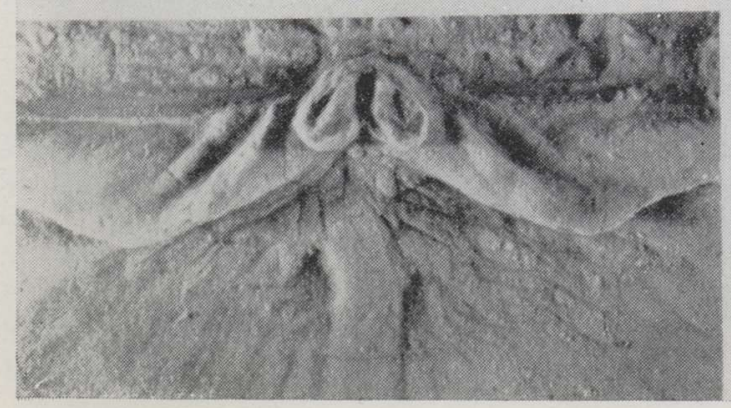

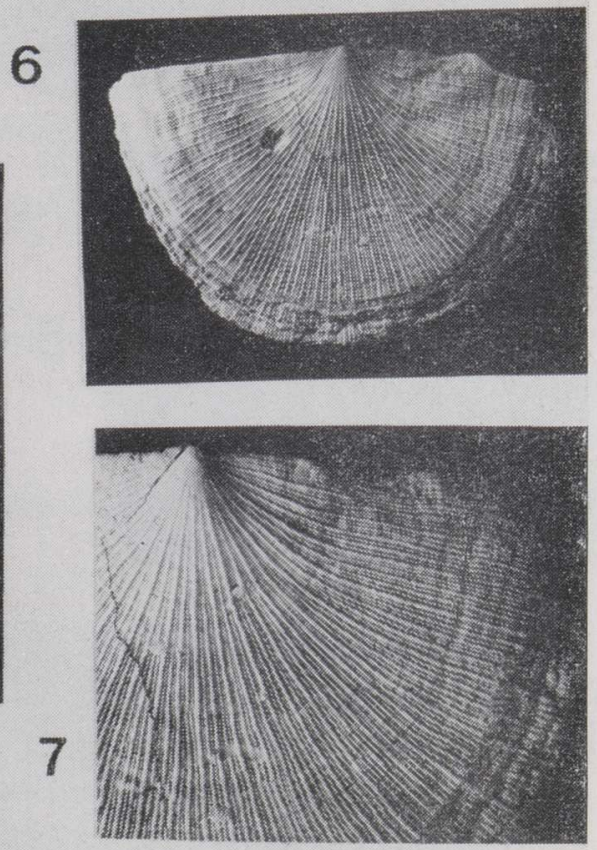

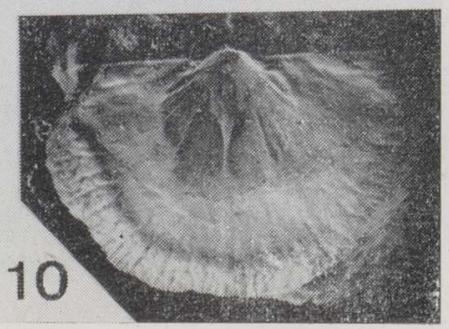



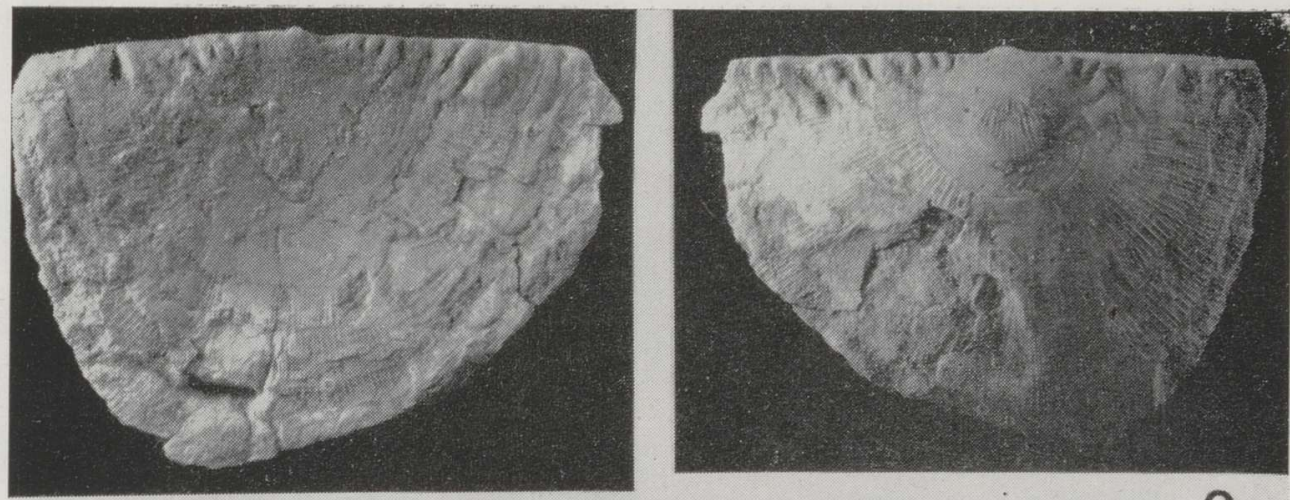

1

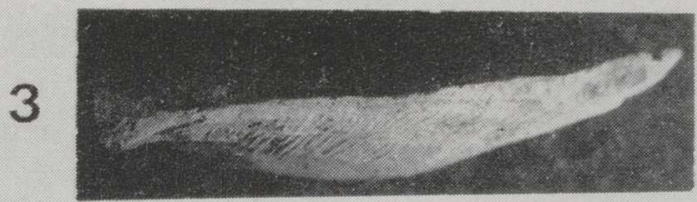

2

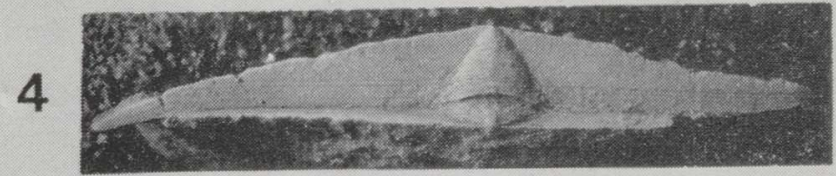

6
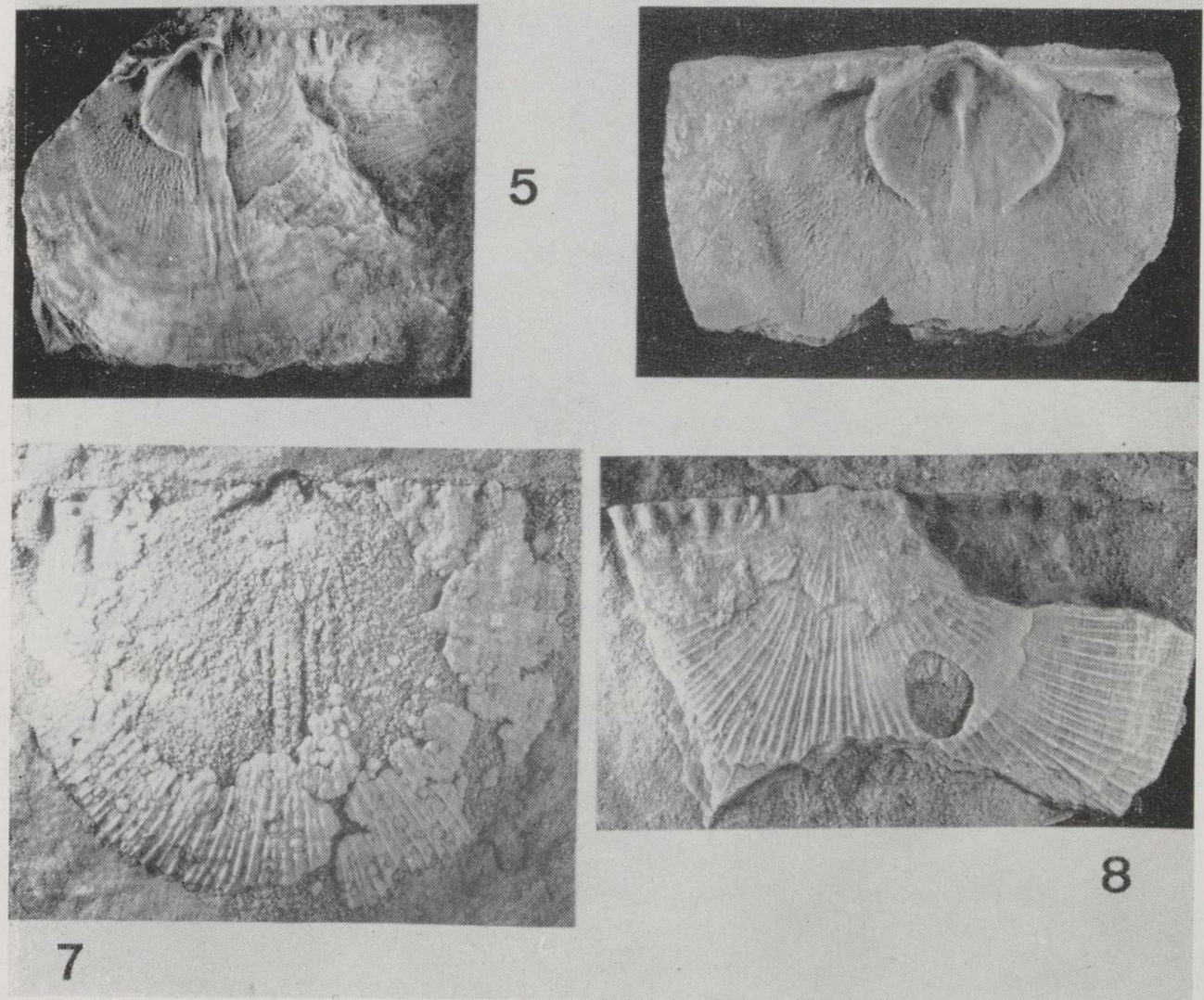
Type species. Luhaia vardi Rõõmusoks (Рыымусокс, 1956, p. 1091); text-figs. 1-4; from the Pirgu Stage, Adila Formation with Röa Member (U. Ashgill), North Estonia.

Diagnosis (emended): Medium-sized Strophomeninae. Shell with sharp ventral geniculation, rounded triangular in outline. Trail longer than disc, medially weakly folded. Disc concentrically rugate, in particular posterolaterally. Ornament unequally parvicostellate with wide spaces between few accentuated costellae. Ventral interarea high, pseudodeltidium large. Ventral muscle field subquadrate, flabellate, with raised bounding ridges and a long medial ridge. Posterior platform small, socket plates short. Cardinal process lobes erect. Short posterior and long anterior transmuscle septa. Breviseptum thin, long. Very fine and dense pseudopunctae.

Species assigned. Luhaia vardi Rõõmusoks (Рыымусокс, 1956, p. 1091; text-figs. $1-4$ ); from the Pirgu Stage; Adila Formation with Röa Member (U. Ashgill), North Estonia (see Pl. II, figs. $1-5$ in the present paper).

Luhaia vardi rõõmusoksi Sheehan, 1987, p. 40; pl. 13, figs. 3-11; from the Fosse Formation (Ashgill), Belgium.

Luhaia ? sp., in Mitchell, 1977, p. 99; pl. 21, figs. 1-6; from Killey Bridge Formation (Ashgill), Ireland.

Luhaia sp. n., mentioned by Wiman (1901, p. 179) as Strophomena aff. euglypha Dalman (Jaanusson, pers. comm.), from the erratic blocks of the Ojle Myr Limestone (U. Ashgill), Gotland, Sweden (see Pl. II, figs. $6-7$ in the present paper).

Luhaia sp. n. from the Boda Limestone (Ashgill), Kallholn, Siljan district, Sweden.

Luhaia sp. n., described by Holtedahl (1916, p. 47; pl. VI, figs. 2, 3 as Strophomena pseudodeltoidea Stolley, 1895) from the 5 a beds ( = Bønsnes Formation, U. Ashgill), Ringerike, Norway.

\section{PLATE III}

Figs. 1-5. Keilamena occidens (Männil), all from Keila Stage (upper part). 1 - dorsal interior $(\times 1)(\mathrm{Br} 2380)$. Kulna. 2 - ventral view $(\times 1)(\mathrm{Br} 2387)$. Jälgimägi, coll. A. Oraspõld, 1951. 3-4 - cardinalia, ventral and posterior views $(\times 2$ and $\times 4.2)$ (Br 2390). Jälgimägi, coll. A. Oraspõld. 5 - ventral interior (X1). Holotype ( $\mathrm{Br} 3091)$. Keila, coll. R. Männil. Figured by Oraspōld (Ораспыльд, 1956, pl. III, fig. 7). Figs. 6-10. Longvillia asmusi (Verneuil), all from Keila Stage (upper part). 6-7 - ventral view and sculpture $(\times 1$ and $\times 2)(\mathrm{Br} 2356)$. Lilli near Kehra, coll. A. Wahl. 8-9 dorsal interior $(\times 1.8$ and $\times 4.7)(\mathrm{Br} 1518)$. Lilli near Kehra, coll. A. Wahl. 10 - ventral interior (X1) ( $\mathrm{Br} 3093)$. Rakvere, coll. A. Öpik.

\section{PLATE IV}

Figs. 1-8. Rugomena adilensis sp. n., all from Pirgu Stage, Adila Formation. 1-2 ventral and dorsal views $(\times 1)$; Holotype $(\mathrm{Br} 1529)$. Vardi, coll. G. Pahnsch. 3 - lateral view (X1.4). Holotype ( $\mathrm{Br} 1529) .4-$ posterior view $(\times 2.2)(\mathrm{Br} 1533)$. Haapsalu, coll. V. Reimer. 5 - ventral interior $(\times 1)(B r 1530)$. Vardi, coll. G. Pahnsch. 6 - ventral interior $(\times 2)(\mathrm{Br} 1531)$. Vardi, coll. G. Pahnsch. 7 - dorsal mould $(\times 2)(\mathrm{Br} 1535)$. Röa, Röa Member, coll. author, 1975. 8 - dorsal view (X2) (Br 1532). Haapsalu, coll. K. Orviku, 1937. 
Remarks. Prof. V. Jaanusson has kindly sent me photos of both interiors of a Luhaia from the Ojle Myr Limestone (erratic block No 17) from Gotland, presumably of Pirgu age. Now for the first time we have the interior of the ventral valve of a Luhaia from the Ordovician of Baltoscandia. The muscle field is like that of Strophomena but subquadrate, somewhat flabellate, with raised bounding ridges and a broad anterior gap. There is a long medial ridge. Prof. V. Jaanusson has sent me for comparison also several specimens of another undescribed Luhaia from the Boda Limestone. Unfortunately, there were no interiors but the external character of the shell appears to be similar to those of the Norwegian species, described by Holtedahl (1916). Examination of the specimens of the latter species in the Paleontologisk Museum, Oslo, convinced me that it was a new Luhaia species, similar to $L$. vardi.

Distribution. Ashgill of Baltoscandia, Ireland, and Belgium.

\section{Genus Keilamena nov.}

Name. After occurrence of the type species in the Keila Stage, particularly in the environs of the town of Keila, north-eastern Estonia.

Type species. Actinomena occidens Männil in Oraspõld (Ораспыльд, 1956, p. 59; pl. III, figs. 7-9; pl. IV, fig. 1), from the upper part of the Keila Stage (U. Caradoc), north-western Estonia.

Diagnosis: Very large Strophomeninae with moderately convexo-concave, gently resupinate, transversely semi-oval or subquadrate shell. Ornament strongly unequally parvicostellate with narrow spaces between numerous accentuated costellae. The latter are more conspicuous on the ventral valve. High ventral interarea, pseudodeltidium and chilidium broad. Ventral muscle field elongately subcircular with raised lateral bounding ridges and striated surface. Long teeth. Cardinal process lobes triangular, stout, erect. Posterior platform small with a short low medial ridge and very short socket plates. No transmuscle septa. Internal surface of the valves smooth but finely and densely pseudopunctate near the valve margins. Straight, long subperipheral ciliar grooves.

Species assigned. Actinomena occidens Männil in Ораспыльд, 1956, p. 59 (see Pl. III, figs. $1-5$ in the present paper).

Strophomena steinari Spjeldnaes, 1957, p. 147; pl. 11, figs. 11, 12; text-figs. 6D, 6H, 6L, 33C from the Coelosphaeridium beds (= Furuberget Formation) (U. Caradoc), Norway.

Discussion. The interiors of Keilamena, particularly the ventral one, are quite similar to those of Tetraphalerella but its size, shape, and radial ornament of the shell are different. Moreover, the latter genus occurs in the considerably younger, Richmondian strata of North America. Our new genus differs from the contemporaneous Longvillia in having larger shell with slightly concave ventral valve, more densely placed accentuated costellae, smaller, elongated ventral muscle field with raised lateral bounding ridges, and short dental plates. Cardinalia of Keilamena is larger than in Longvillia and medial ridge shorter. For comparison with Keilamena photos are given of Longvillia asmusi (Verneuil) from the upper part of the Keila Stage of north-eastern Estonia (see P1. III, figs. 6 -10). To the genus Longvillia should be included also the contemporaneous Strophomena norvegica Spjeldnaes, 1957, from the $4 \mathrm{~b} \alpha-\beta$ beds (= Arnestad and Furuberget Formations) (U. Caradoc) in Norway.

Keilamena steinari (Spjeldnaes) differs from $K$. occidens in having flat, not resupinate ventral valve. Spjeldnaes (1957) did not figure the shell exterior but the internal characters, which suggest Keilamena. 
Distribution. Viru Series of Baltoscandia, Keila Stage in Estonia, and its equivalents in Norway (U. Caradoc).

\section{Genus Rugomena nov.}

Name. From Latin, ruga; referring to the coarse rugae along the hinge line.

Type species. Rugomena adilensis sp. n. from the Pirgu Stage, Adila Formation with the Röa Member (U. Ashgill) of North Estonia.

Diagnosis: Large Strophomeninae with moderately convexo-concave, anteriorly slightly rounded subrectangular shell. Radial ornament strongly unequally parvicostellate with many densely placed accentuated costellae. 4-9 strong short postero-lateral rugae approximately perpendicular to the hinge line. Pseudodeltidium high and wide, chilidium small, not medially grooved. Ventral muscle field subcircular, with sharply raised lateral bounding ridges and broad antero-medial gap. Short posterior medial ridge. Socket plates short. Four long parallel adventitious dorsal septa. Extra-muscular area with densely and irregularly placed small elongated pseudopunctae.

Species assigned. Rugomena adilensis sp. n. (Pl. IV, figs. 1-8). Derivation of name. After Adila Formation, referring to the type horizon.

Holotype. Complete but partly broken shell $(\mathrm{Br} 1529)$ from the Pirgu Stage, Adila Formation from the glacial boulders at Vardi, West Estonia, coll. G. Pahnsch. Diagnosis. Largest Rugomena known (maximum width of the shell $60 \mathrm{~mm}$ ). Shell gently resupinate. Radial ornament with many densely placed accentuated costellae. $8-9$ short strong posterior rugae.

Distribution. Harju Series, Pirgu Stage, Adila Formation with Röa Member. Haapsalu (2 specimens), Piirsalu (1 specimen), Vardi (14 specimens), Röa (2 specimens).

Strophomena vetusta (James), 1874 (see Foerste, 1912, p. 98) from the Richmondian of Ohio, Indiana, Kentucky, U.S.A.

Strophomena kiaeri Holtedahl, 1916, p. 54; pl. IX, figs. 4-6 from 5a beds (= Bønsnes Formation) in Norway.

Strophomena planocorrugata Twenhofel, 1928, p. 194; pl. XVII, figs. $4-5$ from the Richmondian of Anticosti; U. Bighorn Formation, Wyoming, U.S.A.

Discussion. This Strophomena-like new genus includes more or less contemporaneous and closely related species. Generically Rugomena can be distinguished from Strophomena by the character of the dorsal interior, and particularly by the prominent short posterior rugae and strongly unequally parvicostellate radial ornament. Nevertheless, its ventral muscle field is very similar to Strophomena.

Rugomena is apparently of North American Midcontinent origin since the earliest known member of the genus is $R$. vetusta from the Maysvillian or even late Edenian of Wyoming (Macomber, 1970). In Baltoscandia this genus appears as an immigrant in the late Pirgu time associated with some other elements of the American origin new for the region (for example Hebertella, Hypsiptycha, and Maclurites; Рыымусокс, 1964, p. 27).

Distribution. Upper part of the Harju Series of Baltoscandia; U. Bighorn Formation of Wyoming, U.S.A.; Richmondian of North American Midcontinent and Anticosti Island. 


\section{ACKNOWLEDGEMENTS}

The author is deeply indebted to Prof. V. Jaanusson (Swedish Museum of Natural History) for valuable discussions, photos, and loan of specimens of Luhaia from the Boda Limestone for comparison, and Dr. R. L. M. Cocks (British Museum of Natural History) for inspiring discussions in Oslo in 1991. I am indebted also to Prof. D. L. Bruton (Paleontologisk Museum, Oslo) for his kind help during my visit to Norway.

\section{REFERENCES}

Bergström, S. 1971. Conodont biostratigraphy of the Middle and Upper Ordovician of Europe and Eastern North America. - Geol. Soc. Am., Mem., 127, 83-157.

Cocks, L. R. M. 1990. Strophomena de Blainville, 1825 (Brachiopoda): proposed designation of Leptaena planumbona Hall, 1847 as the type species. - Bull. Zool. Nomencl., 47 (4) December, 274-276.

Cooper, G.-A. 1956. Chazyan and related brachiopods. - Smiths. Misc. Coll.

Foerste, A. F. 1912. Strophomena and other fossils from Cincinnatian and Mohawkian horizons, chiefly in Ohio, Indiana, and Kentucky. - Bull. Sci. Laboratories of Denison University, XVII, 1-4, 17-173.

Holtedahl, O. 1916. Strophomenidae of the Kristiania Region. - Vidensk. Selsk. Skrifter. I. Mat.-Naturvidensk. KI. 1915, 12, 1-117.

Jaanusson, V. 1960. The Viruan (Middle Ordovician) of Oland. - Bull. Geol. Inst. Uppsala, 38, 207-288.

Jaanusson, V. 1963. Lower and Middle Viruan (Middle Ordovician) of the Siljan District. - Bull. Geol. Inst. Uppsala, 42, 1-40.

Jaanusson, V. 1982. The Siljan district. - Paleont. Contr. Univ. Oslo, 279, 15-42.

Macomber, R. W. 1970. Artičulate brachiopods from the Upper Bighorn Formation (Late Ordovician) of Wyoming. - J. Paleont., 44, 3, 416-450.

Mitchell, W. I. 1977. The Ordovician Brachiopoda from Pomeroy, Co. Tyrone. Palaeontogr. Soc. (Monogr.), London.

Öpik, A. 1930. Brachiopoda Protremata der estländischen ordovizischen Kukruse Stufe. Acta et Comm. Univ. Tartu, A XVII. 1.

Owen, A. W., Bruton, D. L., Bockelie, J. G. and Bockelie, T. G. 1990. The Ordovician successions of the Oslo region, Norway. - Nor. geol. unders. Special Publ. 4, $3-54$

Rõõmusoks, A. 1985. The genera Trigrammaria and Microtrypa (Strophomenidae) in the Ordovician of Baltoscandia. - Proc. Acad. Sci. Estonian SSR. Geology, 34, 4, $133-140$.

Sheehan, P. M. 1987. Late Ordovician (Ashgillian) brachiopods from the region of the Sambre and Meusa Rivers, Belgium. - Bull. de l'Inst. Royal des Sciences Nat. de Belgique. Sciences de la Terre, 57, 5-81.

Spjeldnaes, N. 1957. The Middle Ordovician of the Oslo Region, Norway, 8. Brachiopods of the suborder Strophomenida. - Norsk Geol. Tidsskrift, 37, 1, 1-214.

Spjeldnaes, N. 1982. The Ordovician of the districts around Mjøsa.-Paleont. Contr. Univ. Oslo, 279, 148-163.

Williams, A. 1962. The Barr and Lower Ardmillian Series (Caradoc) of the Girvan District, south-west Ayrshire, with descriptions of the Brachiopoda. - Geol. Soc. of London Mem., 3.

Williams, A. 1963. The Caradocian brachiopod faunas of the Bala district, Merionethshire. - British Mus. (Nat. History), Geol. Bull., 8, 7, 327-471.

Williams, A. 1965. Strophomenacea. - In: Williams, A. Treatise on Invertebrate Paleontology, H. Brachiopoda. Moore, R. C. (ed.). Lawrence.

Wilson, A. E. 1945. Strophomena and its homeomorphs Trigrammaria and Microtrypa, from the Ottawa Limestone of the Ottawa-St. Lawrence Lowlands. - Royal Soc. Canada, Trans., 39, 4, 121-150. 
Wirnan, C. 1901. Ober die Borkholmer Schicht im Mittelbaltischen Silurgebiet. - Bull. Geol. Inst. Uppsala, 5, 2, 149-222.

Ораспыльд А. 1956. Новые брахиоподы йыхвиского, кейлаского и вазалеммаского горизонтов. - Тр. Ин-та геол. АН ЭССР, І. Таллинн, 41-67.

Рыымусокс А. 1956. Luhaia, новый род строфоменид из верхнего ордовика Эстонской ССР. - Докл. АН СССР, 106, 6, 1091-1092.

Рыымусокс А. 1964. Некоторые брахиоподы из ордовика Эстонии. - Tartu Riikliku Ulikooli Toimetised, 153, 3-28.

Сокольская А. Н. 1954. Строфомениды Русской платформы. - Тр. Палеонтол. ин-та AH CCCP, 51.

\title{
MÕNED BRAHHIOPOODI PEREKONNAD ALAMSUGUKONNAST STROPHOMENINAE EESTI ORDOVIITSIUMIST
}

\section{Arvo ROOMUSOKS}

On esitatud perekonna Actinomena (Opik, 1930) täpsustatud diagnoos. Actinomena asmusi (Verneuil, 1845) on viidud perekonda Longvillia Bancroft, 1933. On kirjeldatud kaks uut perekonda: Keilamena (tüüpliik Actinomena occidens Männil; Ораспыльд, 1956) ја Rugomena (tüüpliik Rugomena adilensis sp. n.). On toodud uusi andmeid perekondade Microtrypa Wilson (1945), Trigrammaria Wilson (1945) ja Luhaia Rõõmusoks (1956) levikust Baltoskandias.

\section{НЕКОТОРЫЕ РОДЫ БРАХИОПОД ИЗ ПОДСЕМЕИСТВА STROРНОМЕNINAE ИЗ ОРДОВИКА ЭСТОНИИ}

\author{
Арво РЫЫМУСОКС
}

Представлен уточненный диагноз рода Actinomena (Öpik, 1930). Actinomena asmusi (Verneuil, 1845) переведен в род Longvillia Bancroft, 1933. Описаны два новых рода: Keilamena, с типовым видом Actinomena occidens Männil (Ораспыльд, 1956), и Rugomena, с типовым видом Rugomena adilensis sp. n. Приведены новые данные о распространении родов Microtrypa Wilson, 1945, Trigrammaria Wilson, 1945 и Luhaia Rõõmusoks, 1956 в Балтоскандии. 